\title{
DIACHRONIC APPROACH TO STUDYING WORD FORMATION SYNONYMY \\ (ON THE EXAMPLE OF VERBS OF THE LEXICO-SEMANTIC GROUP "VERBS OF PLACING AN OBJECT ANYWHERE AS A RESULT OF A CERTAIN ACTION")
}

\author{
Tatyana N. Pavlova ${ }^{1^{*}}$, Evgenia A. Grigoreva ${ }^{2}$, Alena Ju. Nikitina ${ }^{3}$ \\ Svetlana I. Bakhtina ${ }^{4}$, Ekaterina A. Kozhemyakova ${ }^{5}$ \\ Elena A. Ignatieva ${ }^{6}$ \\ ${ }^{1}$ Assoc. Prof., Chuvash State University, RUSSIA, antat12@mail.ru \\ ${ }^{2}$ Assoc. Prof., Chuvash State University, RUSSIA, geva1979@yandex.ru \\ ${ }^{3}$ Assoc. Prof., Chuvash State University, RUSSIA, alyona.nikitina@gmail.com \\ ${ }^{4}$ Assoc. Prof., Chuvash State University, RUSSIA, svetlanabakhtina@yandex.ru \\ ${ }^{5}$ Assoc. Prof., Chuvash State University, RUSSIA, ekozhemyakova@yandex.ru \\ ${ }^{6}$ Assoc. Prof., Chuvash State University, RUSSIA, dima2010ivanoff@mail.ru \\ ${ }^{*}$ Corresponding Author
}

\begin{abstract}
This study is devoted to the consideration of the processes of the emergence and destruction of synonymy in the diachronic aspect between languages of units of two levels - lexical and educational. Moreover, both levels are interconnected and interdependent, since changes in one of them are necessarily on the other. An important role is given to the value of the context in the processes under study. Recognizing the symbolic nature of the language as an exponent of the linguistic picture of the world of its speakers, the authors analyze the reasons for the convergence and divergence of meanings at different time intervals of both the same word and the same root different affix lexemes. The material for the study was the verbs of the lexicosemantic group «Verbs of placing an object anywhere as a result of a certain action», taken in the same context from the lists of the biographies of the Russian saints Boris and Gleb, created at different times and subsequently translated from Old Russian into modern Russian tongue. The main criterion for the selection of linguistic material was the principle of interchangeability of lexemes in the same contexts, since in relation to diachronic synonymy it is fundamental and objectively reflects the linguistic situation of the linguistic period under consideration. In the course of the study, the authors come to the conclusion that the development of synonymous relations between the analyzed verbs «обертеть», «увертеть» and «ввертеть» influenced by the grammatical characteristics of lexemes and their lexical meaning associated with contextual use. And the frequency or singularity of their use is associated not only and not so much with the dictionary meaning, but with the genre of the text in which this or that verb is used.
\end{abstract}

Keywords: synonymy, diachrony, derivational synonym, Russian language.

\section{INTRODUCTION}

Language is a sign system, this postulate in linguistics is generally recognized and beyond doubt. But the sign system of a language is a system of a special kind, the elements of which are material objects for the transmission of information. In accordance with this, not all language units are called signs, but only those that have two-sidedness - they have a plane of expression and a plane of content.

Signs of a special kind include phrases and sentences (super-signs) and morphemes (sub-signs) involved in 
the transmission of information. A person's idea of reality, captured in language units, is called a linguistic picture of the world. The linguistic realization of human thought, feeling, personal attitude to what is happening is part of the linguistic picture of the world either of an individual person, or of the linguistic community as a whole.

The study of the connection between the conceptual and linguistic pictures of the world made it possible for both Russian and foreign linguists to accept the postulate that language is both an instrument of creation, development, storage (in the form of texts) of culture, and its part, since with the help of language they create objectively existing works of material and spiritual culture. The study of the process of receiving, fixing and transmitting information through language is one of the most important issues solved within such a branch of linguistics as cognitive linguistics.

The current state of all language systems is the result of a long and fruitful development of its individual elements over a certain period of time. The changes that have taken place in the language are most clearly reflected, undoubtedly, by its lexical system, which, in turn, is very sensitive to changes in the life of society and the country as a whole. The development of vocabulary, at the same time, is associated with the development of the word-formation system of the language and proceeds with its direct participation. We can say that word formation is the engine of most lexical processes, since it is the main means of forming new words in synthetic languages, in Russian in particular, and, thus, serves to enrich the lexicon.

But, speaking about the influence of word formation on vocabulary, one cannot fail to note the influence of vocabulary on the word-formation system of the language. Under the influence of the lexical meaning of a word, it is possible to change the derivational meaning of the affix forming it - from narrow to wider and vice versa. Such relationships between the two systems result in the development of synonymous relationships between mono-basic different affix lexemes and to such a phenomenon as word-formation synonymy. The diachronic approach allows you to create an objective picture of these processes.

\section{RESULTS}

In linguistics there are different approaches to the definition of synonymy in general and word-formation synonymy in particular. In our opinion, when defining the concept of «word-formation synonym», one should take into account the general typical meaning and the general word-formation correlation of words, as well as their ability to interchange, that is, word-formative synonyms should be understood as different affix formations characterized by a common typical meaning and a general word-formative correlation, similar in meaning and interchangeable in the same or similar lexical compatibility contexts. The principle of interchangeability in this case is very important, since in certain contexts it is the contextual, or speech, synonymy of lexemes that are not synonyms in the language system is possible. This is especially important to take into account in the diachronic approach to the study of synonymy. In the course of the development of the language, the broad synonymous connections that exist between mono-basic different-affix lexemes and are maintained at a certain stage by the context of use are destroyed, since the language ultimately seeks to concretize meanings and destroy polysemy. This leads to the fact that derivational synonyms often diverge in meanings to the extent that it becomes difficult to qualify them as synonyms, since they cease to satisfy one of the main conditions - interchangeability in the same type of contexts.

This process can be illustrated with the help of diachronic analysis of some verbs of the lexico-semantic group «Verbs of placing an object anywhere as a result of a certain action», taken from different-time copies of the text about the biography of the Russian saints Boris and Gleb. As part of this group, we will consider the history of the development of synonymous relations and their decay in verbs обертеть (обернуть) увертеть - ввертеть. In this case, we will take the state of the named verbs in the Old Russian period as a starting point and then consider the changes that occurred to them in subsequent periods of the development of the language up to our time.

Since it was said above that the fundamental principle of allocation of word-formation synonyms is the principle of interchangeability of lexemes, special attention should be paid to the context of the use of these lexemes, because it is in it that the lexical meaning is actualized, on the basis of which the verbs converge as synonyms. In addition, a comparative analysis of the contextual and vocabulary meanings of words allows us to identify the features of the functioning of mono-basic different affix lexical units in a language at a certain time interval and the reasons for the destruction of synonymy within this group of lexemes.

So, the verbs обертеть (обернуть) - увертеть - ввертеть are found in the same context. In this context, the situation is described when the murdered princes-brothers Boris and Gleb are wrapped in a carpet to hide their murder.

This episode is in every chronicle text, as well as in specially created literary texts - «Сказании о Борисе и 
Глебе» and «Страсти и похвале святым мученикам Борису и Глебу». The key word of this episode in each of them is a verb with the meaning of «placing an object somewhere as a result of a certain action»: in some texts it is a verb обертети, in some text ввертети and in one text увертети: Въ ковъръ обертевше, съвесиша ужи на землю (in Sylvester's collection and the Legend of Boris and Gleb); Обертевше в коверъ и ужи съвесиша на землю (Лаврентьевская летопись); Бориса же убивше оканьнии увертевше и в шатеръ (Ипатьевская летопись); Бориса убившее оканнии, ввертеша в шатеръ (Радзивиловская летопись); Блаженаго же Бориса обертевше в шатеръ (Сильвестров сб., Сказание о Борисе и Глебе); Бориса же убивше оканнии увертевше в шатеръ (Новгородская 4-я летопись).

The most common verb oбepmemu recorded in all dictionaries in the Dictionary of the Old Russian Language of the XI-XIV centuries is explained by means of synonyms обвернуть, завернуть which does not give an adequate idea of the meaning of this verb. A more detailed description of it can be found in the Dictionary of the Russian language of the XI-XVII centuries: Обертети: 1. Завернуть, обмотать во что-либо или чем-либо; 2. Обмотать, намотать вокруг чего-либо; 3. Повернуть, заставить повернуться.

Of all the values listed, the first meaning «завернуть, обмотать во что-либо или чем-либо» is precise and specific in relation to the analyzed context.

Attention should also be paid to the fact that the meaning of the verb is emphasized by the presence of a preposition and an indication of the object through which the action is performed: обеpmemu 80 чmo обертети в коверъ/ в шатеръ. The verb обертети is the most used. It occurs in five of the eight examples cited. In second place in terms of usage is the verb yeepmemu (used twice) and in the last place is the verb вверmemu - used only once.

The verb oбepmemu is used in two contexts of the same type in Sylvester's collection and the Legend of Boris and Gleb. These works are artistic and, to a greater extent than chronicle lists, are edifying and correspond to the canon of life.

Chronicle lists, as a rule, have the goal of stating the fact of an action as such, while an artistic life sets the goal of telling about the life of a saint in detail, which means that words should be used in a specific meaning, which we can see in the example of the lexeme обертети. The very word-formative structure of this verb emphasizes the meaning of «обмотать, завернуть во что-либо или чем-либо».

The presence of a prefix 0 - narrows the meaning, makes the perception of the action more tangible, concrete. Other single-root verbs yвертети and ввертети are less commonly used due to the fact that their dictionary meanings are somewhat inconsistent with the context of use. For example, the verb вверmemu in the Dictionary of the Old Russian Language of the XI-XIV centuries has the meaning of «воткнуть, всадить», and in the Dictionary of the Old Russian language XI-XVII centuries - the value «завернуть, поместить внутрь чего-либо свернутого».

If we compare the entries from these dictionaries, we can see that the verbs oбepmemu and вверmemu cannot be synonyms, since it is impossible to «stick» the object of action (in this case, the human body) into a rolled carpet (or tent). In this case, we are faced with a situation where the context affects the meaning of a linguistic unit, and its dictionary meaning as such is overwritten, leveled against the background of the context.

But at the same time, the data of the Dictionary of the Russian language of the XI-XVII centuries justify the use of the verb вверmemu in this contest. Both lexemes - both ввеpmemu, and oбepmemu - converge in the meaning of "wrap an object in something» (this verb - завернуть - is also present in Sreznevsky's «Dictionary of Old Russian Language» as a synonym for wrap) and have a common theme «to put an object inside something». This meaning of the verb ввеpmemu is also supported by the presence of the preposition $B$ and an indication of the place where the object is placed.

Thus, we observe the process of distribution of the meanings of lexemes and derivational formants in the contexts of their use. In the course of this process, certain meanings (primary and secondary) are assigned to lexemes, which are realized when words are used in certain contexts. A word that properly performs its function in a certain context becomes contextually anchored, in this its direct meaning is manifested. When a word is used in an unusual context, it acquires a figurative or contextually determined meaning.

In our case, this phenomenon can be considered using the example of the verbs oбepmemu and вверmemu. The first is used in the considered context in the direct meaning, as evidenced by the wordformation structure of the word: the prefix 0- means «coverage of the whole subject by the action completely». 
The second verb has contextual meaning. If we compare with the data of other time periods, it becomes obvious that the use of the verb oбepmemu (in modern Russian the verb has acquired the form to обернуть) in such contexts is natural since back in the XVIII century. this verb meant «обвивать чем-либо какую-либо вещь», and in modern Russian the lexeme обертети has been transformed into a word form to wrap in the meaning of «завернуть во что-либо, покрыть со всех сторон, обмотать чем-либо» and «обвить, расположить вокруг чего-либо»: wrap a scarf around your neck; wrap the book in a newspaper; wrap the baby in a blanket. But it is unacceptable, for example, to say «вверни ребенка в одеяло» although you can always «ввернуть шуруп в стену».

Here we can observe the development of verbal meanings when changing positions, in this case the object of the action changes: from animate to inanimate. Both verbs began to diverge in their meanings as early as the XIII - XIV centuries in the course of creative selection and taking into account the greatest ability to express the necessary meaning for each of them, its place in the lexical system of the Russian language was determined. For example, in the XVIII century the verb ввертеть (and its forms ввернуть, ввертывать) has the fixed meaning of «вертя что, вонзать, ввинчивать, вертением водружать во что» which is no longer associated with animated objects.

And, as a consequence of this development, in modern Russian the verb ввepmemb is used only with inanimate objects and has a specific meaning «вращая ввести, заставить войти внутрь чего-либо; ввинтить» - ввернуть лампочку - and figurative meaning «ловко, к месту вставить в чью-либо речь слово (замечание, шутку и т.п.)». The verb обернуть has retained its three previous meanings: «завернуть, обмотать во что-либо или чем-либо»; «обмотать, намотать вокруг чего-либо»; «повернуть, заставить повернуться» - and acquired new meanings: «повернуть другой, противоположной стороной; перевернуть; в сказках и поверьях: заставить принять какой-либо вид, облик, превратить в кого-либо, что- либо с помощью колдовства»; разе., устар. «пустив в оборот, вернуть, получить обратно»; «то же, что обернуться во втором значении - быстро вернуться». Тhe verb увертетu was used in the XVIII century in meaning «увивать вокруг: увертеть младенца пеленками» (Dictionary of the Russian Academy) and which in this regard was the semantic equivalent of the verb oбepmemu, in modern Russian it fell out of use, since it became superfluous, redundant: the verbs обернуть and ввертеть distributed the spheres of use among themselves.

\section{CONCLUSIONS}

Thus, using the diachronic approach to the analysis of language, one can see the result of a long process of development of synonymous relations and their destruction between lexemes and their constituent affixes. An example of this in modern Russian is the relationship between monobasic different affix verbs oбepmemb (обернуть) - ввертеть - увертеть included in the lexical-semantic group «Verbs of placing an object somewhere as a result of a certain action»: the synonymous connections between them broke up due to the fact that they were more contextually determined, over time, the dictionary meanings of these verb tokens diverged and the objects of action changed. These processes reflect not only changes in the system of the language itself, they are also signs of changes in the perception of reality by native speakers of this language, their desire for a more accurate expression of knowledge about the world.

\section{REFERENCE LIST}

Aminova, A.A. (1988). Verb synonyms of the Russian language (in Russian).

Efremova, T.F. (2006). Modern explanatory dictionary of the Russian language (in Russian).

Sternin, I.A. (1982) Speech synonymy of lexemes on the peripheral components of meaning. Materials on the problems of synonymy (issue 3 ) (in Russian).

Dictionary of the Old Russian language XI - XIV centuries. In 10 volumes (1988 - 2002) (in Russian).

Dictionary of the Russian language. In 4 volumes (Russ. ed.: A. P. Evgenieva) (1983) (in Russian).

Dictionary of the Russian Academy. In 6 volumes (789-1794) (in Russian).

Sreznevsky, I.I. Dictionary of the Old Russian language. In 3 volumes (1989) (in Russian). 